\title{
DEVELOPING APPRECIATIVE LITERATURE TEXTBOOK BASED ON THEMATIC- INTEGRATIVE THROUGH ACTIVE LEARNING TO IMPROVE UNDERGRADUATE STUDENTS' APPRECIATIVE CAPABILITY ON POETRY AND DRAMA IN ELEMENTARY TECHER EDUCATION PROGRAM
}

\author{
Endang Sri Markamah, St. Y. Slamet, Rukayah, Retno Winarni \\ Universitas Sebelas Maret \\ endangsri775@yahoo.com
}

Article History

accepted 09/07/2018

approved 01/08/2018

published 17/09/2018

\section{Keywords}

textbook, poetry dan drama, an appreciative, thematic-integrative, active learning

\begin{abstract}
The objectives of this research were: (1) to describe students' and lecturers' needs on poetry and drama appreciative textbook, (2) to describe the development of textbook model (3) to find the effectiveness of textbook model 4) to describe textbook dissemination. The type of research used was research and development. Research was done through 4 stages: (1) exploration, (2) model development, (3) model testing, (4) dissemination. Exploration stage used qualitative descriptive approach. Data was collected through in-depth interviews, observation, documentation, and questionnaires. Data analysis technique was interactive analysis model. Model testing was done through experimental research. The results of this research were: (1) the exploration stage showed that the poetry and drama learning textbook used by Elementary Teacher Education Program (ETEP) studentsin Surakarta did not meet the students' and lecturers' need, (2) model development stage producedappreciative poetry and drama textbook through preliminary field testing; (3) model testing phase was to test effectiveness of the textbook used t-test non-independent technique.It was obtained tobtainof 23 and

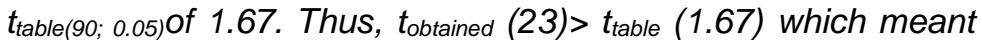
that the hypothesis was accepted (Ho was rejected). In conclusion, the Appreciative Poetry and Drama textbook model was effectively improve students' poetry and drama appreciation skills. Dissemination was done through national seminars, article writing in international journals, as well as the publishing of an Integrative-thematic Textbook of Poetry and Drama Learning with ISBN.
\end{abstract}

Social, Humanities, and Education Studies (SHEs): Conference Series https://jurnal.uns.ac.id/shes

p-ISSN 2620-9284 e-ISSN 2620-9292 


\section{PENDAHULUAN}

Kondisi yang terjadi dalam pembelajaran sastra di Prodi S1 PGSD daerah Surakartahasilnya masih belum menggembirakan.Oleh karena itu, hal ini penting untuk dilakukan upaya pengembangan buku teks pembelajaran sastra yang apresiatif berbasis tematik integratifmelalui active Learning. Buku teks yang diharapkan adalah yang lebih tepat, sesuai dengan kebutuhan dan karakteristik mahasiswa, sehingga dapat membantu untuk meningkatkan kemampuan mengapresiasipuisi dan drama.

Permasalahan lain yang ditemui drama adalah proses pembelajaran sastra masih secara konvensional. Pembelajaran didominasi oleh dosen. Dosen kurang memiliki bahan ajar yang memadai serta cara penyajiannya tidak sesuai dengan minat dan kondisi mahasiswa. Hal ini menyebabkan pembelajaran membosankan dan tingkat apresiasi sastra menjadi rendah. Hal ini terjadi karena salah satu diantaranya bahan ajar yang disajikan kurang sesuai dengan konteks yang ada.

Berdasarkan hasil wawancara mendalam dengan mahasiswa dan dosen, kemampuan mengapresiasi sastra (puisi dan drama) mahasiswa Prodi S1 PGSD daerah Surakarta sebagai calon guru sekolah dasar belum berhasil secara maksimal. Kekurangberhasilan tersebut dikarenakan faktor strategi pembelajarannya yang kurang apresiatif dan integratif. Pembelajaran apresiasi sastra belum diajarkan untuk menikmati, menghargai, menilai, dan memanfaatkan karya sastra untuk mengembangkan kepribadian, memperluas wawasan kehidupan, serta meningkatkan keterampilan berbahasa.

Fenomena kurang berhasilnya pembelajaran sastra di Prodi S1 PGSD dapat dikatakan paling dominan saat ini adalah rendahnya tingkat kemampuan mengapresiasi puisi dan drama mahasiswa. Hal ini disebabkan adanya keterbatasan buku teks sebagai acuan. Buku-buku perkuliahan yang ada atau yang biasa digunakan belum sepenuhnya menunjang keberhasilan kemampuan mengapresiasi puisi dan drama mahasiswa. Dosen belum melaksanakan pembelajaran dengan menggunakan medel pembelajaran yang inovatif.

Pembelajaran aktif merupakan kegiatan-kegiatan yang membantu mahasiswa untuk menguji perasaan-perasaan, nilai-nilai, dan perilaku mereka (Silberman, 2006: 5). Silberman menggambarkan saat belajar aktif, mahasiswa melalukan banyak kegiatan. mahasiswa menggunakan otak untuk mempelajari ide-ide, memecahkan masalah, dan menerapkan apa yang mereka pelajari. Menurut Lorenzen (2001: 19) pembelajaran aktif adalah suatu metode dalam mendidik atau mengajak mahasiswa untuk berpartisipasi aktif di dalam kelas. Pembelajaran aktif bertujuan untuk mengoptimalkan penggunaan semua potensi yang dimiliki oleh siswa, sehingga semua mahasiswa dapat mencapai hasil belajar yang memuaskan sesuai dengan karakteristik pribadi yang mereka miliki.

Penelitian Cherney (2008) menyimpulkan bahwa penerapan pembelajaran aktif berdasarkan tingkat program atau materi, tipe siswa, tipe kelas, serta diskusi yang dibutuhkan mahasiswa untuk meningkatkan pemahaman materi. Meyers \& Jones (1993) menyimpulkan bahwa penerapan strategi pembelajaran aktif, mahasiswa dapat berekspresi dalam empat ranah keterampilan berbahasa yakni, menyimak, berbicara, membaca, dan menulis. Kedua peneliti tersebut membuktikan bahwa pembelajaran aktif dapat meningkatkan kemampuan mengapresiasi puisi dan drama. 
Hasil penelitian Prince (2004) menyimpulkan bahwa pemilihan strategi pembelajaran aktif dalam pembelajaran merupakan suatu pertimbangan yang tepat untuk mengefektifkan pembelajaran. Pembelajaran aktif merupakan teknik mengajar yang efektif bila dibandingkan dengan teknik mengajar konvensional. Keuntungan penerapan pembelajaran aktif yakni: (1) mahasiswa akan belajar lebih banyak materi; (2) mahasiswa dapat menyimpan informasi lebih lama; dan (3) mahasiswa lebih dapat menyukai pembelajaran, guru, dan kondisi kelas sebagai sesuatu hal yang baru dan sangat bervariasi. Pembelajaran aktif memungkinkan mahasiswa untuk belajar dalam kelas dengan bantuan guru atau tanpa guru dan mahasiswa yang lain.

Penelitian Mustakim (2010) menyimpulkan bahwa pembelajaran apresiasi sastra di sekolah baru sebatas pemahaman literer, belum menyentuh kemampuan inferensial, evaluatif, dan apresiatif. Hal itu tidak lepas dari kenyataan umum bahwa pembelajaran sastra di sekolah yang masih berada pada sekitar pembicaraan tentang sastra, menghafal karya, dan pelaksanan pembelajarannya dengan menggunakan metode ceramah. Masalah yang sering terjadi dalam pembelajaran sastra belum mampu membuat mahasiswa memiliki pemahaman terhadap daya tarik sastra dan tujuan utama pembelajaran sastra.

Pembelajaran sastra yang baik harus mampu membantu keterampilan berbahasa mahasiswa, meningkatkan pengetahuan budaya, mengembangkan cipta dan rasa, dan menunjang pembentukan watak (Moody, 1971: 15). Tujuan pembelajaran sastra adalah agar pembelajar mampu menikmati, memahami, dan memanfaatkan karya sastra untuk mengembangkan kepribadian, memperluas wawasan kehidupan, serta meningkatkan pengetahuan dan kemampuan berbahasa (Nurhidayati, 2011, 87). Adapun tujuan utama pengajaran sastra adalah memberikan kesempatan kepada pembelajar untuk memperoleh pengalaman sastra dengan sasaran akhir mampu mengapresiasi sastra (Gani, 1998, 15). Dilihat dari nilai pendidikan, sastra memiliki manfaat (1) mempercepat perkembangan bahasa, melalui kegiatan mendengarkan dan membaca sastra, (2) mengembangkan keterampilan menulis, karena terdapat korelasi antara keterampilan membaca yang dimiliki dan keterampilan menulis, dan (3) mengembangkan kemampuan lintas kurikulum, yaitu dengan belajar berbagai pengetahuan melalui sastra (Supriyadi, 2007: 9).

Dalam pembelajaran bahasa dan sastra, konsep integratif mengacu pada pengertian penyajian materi pembelajaran bahasa dan sastra secara terpadu. Materi kebahasaan (struktur dan kosa kata) dengan keterampilan (mendengarkan, berbicara, membaca, dan menulis) dalam pelaksanaan kegiatan pembelajaran, penyajian materi tersebut disajikan secara terpadu atau integratif. Kegiatan mendengarkan sastra dapat diintegrasikan dengan kegiatan berbicara, misalnya, menceritakan kembali, tanya jawab, diskusi/meminta tanggapan secara lisan. Di samping itu, kegiatan mendengarkan dapat diintegrasikan dengan membaca, menulis, bahkan keempat keterampilan berbahasa sekaligus.

Keberhasilan pembelajaran sastra yang apresiatif dan integratif perlu tersedianya buku teks pembelajaran puisi dan drama yang apresiatif berbasis tematik integratif . Buku teks berisi materi spesifik bidang ilmu tertentu yang digunakan sebagai pedoman belajar dan mengajar di sekolah (Richards \& Rodgers, 2002: 550). Buku teks biasanya digunakan bersama-sama dengan sumber belajar lain seperti workbook, buku referensi guru atau teks pendukung (Tomlinson \& Masuhara, 2008:14). Guna 
kepentingan pemenuhan buku teks tersebut, maka penelitian ini mendesak dan perlu segera dilakukan pada Program Studi S1 PGSD daerah Surakarta.

\section{METODE PENELITIAN}

Jenis penelitian yang dipergunakan dalam penelitian ini adalah penelitian pengembangan yang dikembangkan oleh Borg dan Gall (2003: 772). Selanjutnya, Borg dan Gall mengatakan bahwa penelitian dan pengembangan merupakan proses yang digunakan untuk mengembangkan dan memvalidasi produk pendidikan. Penelitian ini meliputi empat tahapan yakni: (1) tahap pendahuluan, (2) tahap pengembangan model, (3) tahap pengujian model, dan (4) tahap diseminasi dan implementasi model (Sukmadinata, 2010: 182- 189; Nurkamto, 2012: 2-5).

Tahap eksplorasi dilakukan kajian yang mendalam terhadap pelaksanaan pembelajaran puisi dan drama yang apresiatif berbasis tematik integratif pada Program Studi S1 PGSD daerah Surakarta. Tujuan kegiatan ini adalah untuk melakukan analisis kebutuhan mahasiswa dan dosen terhadap buku teks yang dianggap mampu meningkatkan kemampuan mengapresiasi puisi dan drama mahasiswa secara optimal. Pendekatan penelitian yang dipergunakan adalah pendekatan deskriptif kualitatif. Peneliti menekankan pengamatan terhadap interaksi antara mahasiswa dan dosen dalam pelaksanaan pembelajaran apresiasi puisi dan drama di lokasi penelitian. Peneliti juga melakukan wawancara dan menyebar angket kepada mahasiswa dan dosen, melakukan analisis terhadap dokumen-dokumen yang berkaitan dengan masalah penelitian.

Data penelitian ini diperoleh dari berbagai sumber data yang tersedia di lokasi penelitian. Jenis sumber data yang dipergunakan adalah: 5 orang mahasiswa dan 5 orang dosen, peristiwa kegiatan pembelajaran apresiasi puisi dan drama di dalam kelas, dan dokumen atau arsip. Teknik pengumpulan data yang dipergunakan adalah wawancara mendalam, observasi, dokumentasi, dan angket. Analisis data terhadap data penelitian ini dilakukan dengan model analisis interaktif (Miles dan Huberman, 1992: 16-20; Sutopo, 2002, 95-96), yang dilaksanakan dalam 2 tahap, yakni: pada saat atau selama berlangsungnya pengumpulan data dan setelah pengumpulan data.

Pada tahap pengembangan model, tujuan utamanya adalah dihasilkannya model buku tekspembelajaran puisi dan drama yang apresiatif berbasis tematik integratif. Pengembangan prototipe model buku teks dilakukan dalam bentuk siklus, yang merupakan perpaduan antara riset dan praktik (Gall et al, 2003: 578). Langkahlangkah yang dilakukan meliputi: penyiapan prototipe, implementsi, evaluasi pelaksanaan, dan revisi secara berkelanjutan. Prosedur yang digunakan adalah 
panduan teori model Glanz (dalam Gall et al, 2003: 585-590), yang meliputi: pengumpulan data, analisis, interpretasi data, tindakan refleksi, dan modifikasi. Selanjutnya, pada siklus berikutnya dengan prosedur yang sama. Selain itu, juga digunakan model Zuber-Skeritt (dalam Cohen, 2000: 235), yang meliputi: perencanaan yang matang, penerapan rencana, pengamatan, penilaian, evaluasi, analisis kritis hasil pelaksanaan, dan penentuan siklus selanjutnya.

Bentuk pengembangan dilakukan dengan cara mengujicobakan draf model buku teks di lapangan, melalui uji coba terbatas dan uji coba luas. Uji coba terbatas dilakukan pada Program Studi S1 PGSD UNS Surakarta. Uji coba luas dilakukan pada Program Studi S1 PGSD UMS Surakarta dan Program Studi S1 PGSD UNISRI Surakarta.

Teknik pengumpulan data yang dipergunakan adalah wawancara mendalam, observasi partisipan, analisis dokumen, tes, dan diskusi kelompok terfokus. Analisis data dilakukan dengan dua cara, yaitu secara kualitatif dan secara kuantitatif. Model yang telah diujicobakan kemudian dikonsultasikan kepada pakar dengan tujuan agar model buku teks yang dikembangkan memiliki kebenaran substantif dan kualitasnya. Adapun pakar yang melakukan validasi, yaitu Prof. Dr. Herman J. Waluyo, M. Pd. (pakar pembelajaran sastra) dosen Universitas Sebelas Maret Surakarta.

Tahap pengujian model bertujuan untuk menguji keefektifan model buku teks pembelajaran sastra yang apresiatif berbasis tematik integratif dalam meningkatkan kemampuan mengapresiasi puisi dan drama mahasiswa. Pengujian model dilakukan dengan melakukan penelitian eksperimen. Jenis penelitian eksperimen yang digunakan adalah penelitian kuasi eksperimen (quasi experiment). Rancangan penelitian eksperimen yang dipilih adalah Quasy-eksperimental Design ModelNonequivalent Before-after Design (Wiersma, 1986: 143-144; Cohen et al, 2000: 216; Sugiyono 2013: 302-305). Prosedur eksperimen yang digunakan adalah konsep Gall, Gall, \& Borg (2003: 381) dan Cohen (2000: 216).

Kelas eksperimen yang digunakan yaitu mahasiswa Program Studi S1 PGSD UNS Surakarta sebanyak 90 orang mahasiswa. Kelas kontrolnya yaitu mahasiswa Program Studi S1 PGSD UMS Surakarta sebanyak 90 orang mahasiswa. Rancangan penelitian ini akan melihat pengaruh utama dari variabel perlakuan buku teks pembelajaran sastra yang apresiatif berbasis tematik integratif terhadap kemampuan mengapresiasi puisi dan drama mahasiswa.

Teknik pengumpulan data yang digunakan adalah tes kemampuan mengapresiasi puisi dan drama. Analisis data penelitian dilakukan melalui dua tahap, yaitu tahap uji 
persyaratan analisis (uji normalitas, uji homogenitas, dan uji keseimbangan) dan tahap analisis data untuk menguji keefektifan model, yaitu dengan uji beda rata-rata ( $\mathbf{u j i} \mathbf{- t}$ non-independen). Luaran dari tahap pengujian model adalah buku teks pembelajaran puisi dan drama yang apresiatif berbasis tematik integratif yang telah teruji secara proses dan secara produk.

Tahap diseminasi ini disosialisasikan buku teks pembelajaran puisi dan drama yang apresiatif berbasis tematik integratif yang telah dikembangkan dengan harapan agar buku teks tersebut dapat diimplementasikan pada pembelajaran puisi dan drama yang apresiatif khususnya pada LPTK-LPTK yang meniliki Program Studi S1 PGSD di daerah Surakarta. Diseminasi dilakukan melalui seminar nasional, penulisan artikel di jurnal internasional, serta penerbitan Buku Teks Pembelajaran Puisi dan Drama yang Apresiatif berbasis tematik integratif ber-ISBN.

\section{HASIL PENELITIAN DAN PEMBAHASAN}

Berdasarkan hasil temuan pada tahap eksplorasi dapat disimpulkan bahwa terdapat permasalahan dalam pembelajaran sastra di Program Studi S1 Pendidikan Guru Sekolah Dasar (PGSD). Permasalahan tersebut yakni, (1) belum adanya buku teks pembelajaran puisi dan drama yang apresiatif berbasis tematik integratif, (2) belum adanya tindakan untuk meningkatkan kemampuan mengapresiasi puisi dan drama mahasiswa, (3) dosen kurang memahami materi apresiasi puisi dan drama yang apresiatif, dan (4) dosen belum menggunakan model pembelajaran inovatif. Pada prinsipnya mahasiswa, dosen, dan pengambil kebijakan menyepakati bahwa buku teks pembelajaran puisi dan drama yang apresiatif berbasis tematik integratif perlu segera disusun (tersedia). Selanjutnya, berdasarkan analisis kebutuhan mahasiswa dan dosen, diperoleh hasil berikut (1) buku teks pembelajaran puisi dan drama yang apresiatif berbasis tematik integratif perlu segera disusun (tersedia) untuk mempermudah dan memandu mahasiswa meningkatkan kemampuan mengapresiasi puisi dan drama mahasiswa, (2) prosedur pembelajaran inovatif (active learning) sangat diperlukan untuk diterapkan sebagai solusi atas kejenuhan mahasiswa dalam perkuliahan yang monoton dan tidak bervariasi, dan (3) perlu menggunakan penedekatan tematik integratif yang dapat membantu meningkatkan kemampuan mengapresiasi puisi dan drama mahasiswa.

Berdasarkan hasil temuan pada tahap eksplorasi yang memuat analisis kebutuhan mahasiswa dan dosen, terdapat enam upaya yang dilakukan pada tahap pengembangan ini. Upaya tersebut yakni; (1) pengembangan prototipe model menjadi model buku teks pembelajaran puisi dan drama yang apresiatif berbasis tematik integratif, (2) hasil pengembangan prototipe model berdasarkan expert's judgement, (3) hasil pengembangan dan perbaikan model berdasarkan uji coba terbatas di Program Studi S1 PGSD daerah Surakarta, (4) hasil pengembangan model berdasarkan uji coba yang lebih luas di Program Studi S1 PGSD daerah Surakarta, (5) penetapan model buku teks di Program Studi S1 PGSD daerah Surakarta, dan (6) 
simpulan hasil pengembangan model buku teks pembelajaran puisi dan drama yang apresiatif berbasis tematik integratif di Program Studi S1 PGSD daerah Surakarta.

\section{Tahap Pengujian Model}

\section{Deskripsi Data Kemampuan Mengapresiasi Puisi dan Drama}

Pengujian model buku teks pembelajaran puisi dan drama yang apresiatif berbasis tematik integratifini dilakukan dengan memberikan pretes kepada 90 mahasiswa S1 PGSD daerah Surakarta sebelum eksperimen dilaksanakan. Selanjutnya, setelah eksperimen, kepada 90 mahasiswa tadi diberikan postes. Pretes diselenggarakan untuk mengetahui secara konkret, kemampuan mengapresiasi puisi dan drama mahasiswa sebelum pelaksanaan eksperimen dilakukan. Sebaliknya, postes dilaksanakan untuk mengetahui secara konkret pula, kondisi akhir kemampuan mengapresiasi puisi dan drama mahasiswa sesudah eksperimen dilangsungkan.

Mengacu kepada penjelasan tersebut, deskripsi data penelitian pada tahap pengujian model ini ada dua, yaitu: a. data skor pretes kemampuan mengapresiasi puisi dan drama, dan b. data skor postes kemampuan mengapresiasi puisi dan drama.

\section{a. Data Skor Pretes Kemampuan Mengapresiasi Puisi dan Drama}

Berdasarkan analisis secara deskriptif yang dilakukan dengan program Excel 2003, data nilai pretes kemampuan mengapresiasi puisi dan drama mahasiswa S1 PGSD daerah Surakarta, dapat dilaporkan: (1) tendensi sentral (kecenderungan memusat), meliputi: mean $=52,07 ;$ modus $=60$; dan median $=53,5 ;$ (2) tendensi penyebaran (kecenderungan menyebar), meliputi: varians $=81,37$; dan standar deviasi $=9,02$; (3) nilai terbesar $=74$; dan nilai terkecil $=30$; (4) rentangan $=44$.

Distribusi frekuensi skor pretes kemampuan mengapresiasi puisi dan drama diperoleh melalui tahapan penghitungan sebagai berikut:

1) menentukan rentang, yakni dengan mengurangi data terbesar dengan data terkecil. Data terbesar 74 dan data terkecil 30 . Setelah dilakukan penghitungan diperoleh nilai rentang 44;

2) menentukan banyak kelas interval. Pada penelitian ini digunakan 6 kelas interval;

3) menentukan panjang kelas interval dengan cara nilai rentang dibagi banyak kelas interval. Setelah dilakukan penghitungan diperoleh hasil 44: $6=7,33$, yang kemudian dibulatkan menjadi 8.

4) memilih ujung bawah kelas interval pertama. Hal ini dilakukan dengan mengambil data terkecil. Oleh karena itu, kelas interval pertama dimulai dari skor 30. 
Berdasarkan langkah-langkah penyusunan disribusi frekuensi skor di atas, maka distribusi frekuensi skor pretes kemampuan mengapresiasi puisi dan drama mahasiswa sebelum dilakukan eksperimen dapat dilihat pada Tabel 1 berikut.

Tabel 1. Distribusi Frekuensi Skor Pretes kemampuan mengapresiasi puisi dan drama Sebelum dilakukan Eksperimen

\begin{tabular}{|c|c|c|}
\hline kelas Interval & $\begin{array}{c}\text { frekuensi absolut } \\
\left(f_{\text {abs }}\right)\end{array}$ & $\begin{array}{c}\text { frekuensi relatif (\%) } \\
\left(f_{\text {rel. }}\right)\end{array}$ \\
\hline $30-37$ & 6 & 6,67 \\
\hline $38-45$ & 15 & 16,67 \\
\hline $46-53$ & 24 & 26,67 \\
\hline $54-61$ & 36 & 40,00 \\
\hline $62-69$ & 8 & 8,89 \\
\hline \multirow[t]{2}{*}{$70-77$} & 1 & 1,11 \\
\hline & 90 & 100,00 \\
\hline
\end{tabular}

\section{b. Data Nilai Postes Kemampuan Mengapresiasi Puisi dan Drama}

Berdasarkan analisis secara deskriptif yang dilakukan dengan program Excel 2003, data nilai postes kemampuan mengapresiasi puisi dan dramamahasiswa S1 PGSD daerah Surakarta, dapat dilaporkan: (1) tendensi sentral (kecenderungan memusat), meliputi: mean $=74,96 ;$ modus $=78$; dan median $=75,5 ;$ (2) tendensi penyebaran (kecenderungan menyebar), meliputi: varians $=35,46$; dan standar deviasi $=5,95$; (3) nilai terbesar $=88$; dan nilai terkecil $=60$; (4) rentangan $=28$. Sebagaimana tahapan atau langkah-langkah penyusunan distribusi frekuensi skor pretes kemampuan mengapresiasi puisi dan drama, maka dengan melakukan kegiatan penghitungan yang sama tersebut, penyusunan distribusi frekuensi skor postes kemampuan mengapresiasi puisi dan drama, setelah dilakukan penghitungan diperoleh: (1) rentang = 28; (2) bayak kelas interval ditetapkan 6; (3) panjang kelas interval = 4,67 dibulatkan 5; dan (4) ujung bawah kelas interval pertama dimulai dari data terkecil yaitu 60 .

Berdasarkan langkah-langkah penyusunan disribusi frekuensi skor di atas, maka distribusi frekuensi skor postes kemampuan mengapresiasi puisi dan dramamahasiswa setelah dilakukan eksperimen dapat dilihat pada Tabel 2 berikut. 
Tabel 2. Distribusi Frekuensi Skor Postes kemampuan mengapresiasi puisi dan drama mahasiswa Setelah dilakukan Eksperimen

\begin{tabular}{ccc}
\hline kelas Interval & $\begin{array}{c}\text { frekuensi absolut } \\
\left(\mathbf{f}_{\text {abs }}\right)\end{array}$ & $\begin{array}{c}\text { frekuensi relatif }(\%) \\
\left(\mathbf{f}_{\text {rel. }}\right)\end{array}$ \\
\hline $60-64$ & 3 & 3,33 \\
\hline $65-69$ & 14 & 15,56 \\
\hline $70-74$ & 26 & 28,89 \\
\hline $75-79$ & 23 & 25,56 \\
\hline $80-84$ & 20 & 22,22 \\
\hline $85-89$ & 4 & 4,44 \\
\hline & 90 & 100,00 \\
\hline
\end{tabular}

\section{Pengujian Persyaratan Analisis}

Analisis data secara inferensial untuk membuktikan apakah hipotesis penelitian ini diterima/ditolak digunakan uji statistik dengan uji-t non-independent. Analisis data dengan teknik statistic ini diperlukan beberapa persyaratan mengenai data yang akan dianalisis. Persyaratan itu mencakupi: (a) uji normalitas data, dan (b) uji homogenitas varians.

Uji normalitas data dilakukan dengan menggunakan teknik uji Lilliefors. Sementara itu, uji homogenitas varians dilakukan dengan menggunakan teknik ujiBartlett.

\section{a. Uji Normalitas Data}

Data yang diuji normalitasnya dalam penelitian ini ada dua, yaitu (1) data skor pretes kemampuan mengapresiasi puisi dan dramamahasiswa sebelum eksperimen dilakukan, dan (2) data skor postes kemampuan mengapresiasi puisi dan dramamahasiswa setelah eksperimen dilakukan. Berikut hasil uji normalitas untuk kedua kelompok data di atas.

1) Hasil Uji Normalitas Data Skor Pretes Kemampuan Mengapresiasi Puisi dan Drama mahasiswa Sebelum Eksperimen Dilakukan

Pengujian normalitas terhadap data skor pretes kemampuan mengapresiasi puisi dan dramamahasiswa sebelum eksperimen dilakukan menghasilkan $L_{o}$ maksimum sebesar 0,0699. Dari daftar nilai kritis $L$ untuk uji Lilliefors dengan $n=90$ dan taraf nyata $\alpha=0,05$ diperoleh $L_{t}=0,0934$. Dari perbandingan di atas tampak bahwa $L_{o}$ ebih kecil daripada $L_{t}$, sehingga dapat disimpulkan bahwa data skor pretes kemampuan mengapresiasi puisi dan dramamahasiswa sebelum eksperimen dilakukan berasal dari populasi yang berdistribusi normal. 


\section{2) Hasil Uji Normalitas Data Skor Postes Kemampuan Mengapresiasi Puisi dan Drama mahasiswa Setelah Eksperimen Dilakukan}

Pengujian normalitas terhadap data skor postes kemampuan mengapresiasi puisi dan dramamahasiswa setelah eksperimen dilakukan menghasilkan $L_{o}$ maksimum sebesar 0,0778. Dari daftar nilai kritis $L$ untuk uji Lilliefors dengan $\mathrm{n}=90$ dan taraf nyata $\alpha=0,05$ diperoleh $L_{t}=0,0934$. Dari perbandingan di atas tampak bahwa $L_{o}$ lebih kecil daripada $L_{t}$, sehingga dapat disimpulkan bahwa data skor postes kemampuan mengapresiasi puisi dan dramamahasiswa setelah eksperimen dilakukan berasal dari populasi yang berdistribusi normal.

\section{b. Hasil Uji Homogenitas Varians}

Pengujian homogenitas varians ini dilakukan untuk menguji kesamaan variansi antara skor pretes kemampuan mengapresiasi puisi dan drama(sebelum eksperimen), dan skor postes kemampuan mengapresiasi puisi dan drama(setelah eksperimen). Teknik statistik yang digunakan untuk kepentingan ini adalah dengan teknik uji Bartlett. Pengujian ini dimaksudkan untuk menguji hipotesis nol $\left(H_{0}\right)$ yang menyatakan bahwa varians antara skor pretes (sebelum eksperimen) kemampuan mengapresiasi puisi dan drama dan skor postes (setelah eksperimen) kemampuan mengapresiasi puisi dan dramaadalah homogen pada taraf nyata $\alpha=0,05$, melawan hipotesis tandingannya $\left(H_{1}\right)$ yang menyatakan bahwa varians antara skor pretes (sebelum eksperimen) kemampuan mengapresiasi puisi dan dramadan skor postes (setelah eksperimen) kemampuan mengapresiasi puisi dan dramaadalah tidak homogen pada taraf nyata yang sama.

Kriteria pengujian yang digunakan ialah bahwa $H_{0}$ ditolak jika ternyata harga $\chi_{\text {hitung }}^{2}$ lebih kecil atau sama dengan $(\leq) \chi_{\text {tabel }}^{2}$ pada taraf nyata $\alpha=0,05$. Sebaliknya, jika harga $\chi_{\text {hitung }}^{2}>\chi_{\text {tabel }}^{2}$ pada taraf nyata $\alpha=0,05$, maka $H_{0}$ yang menyatakan bahwa varians skor homogen diterima.

Pengujian homogenitas varians skor pretes (sebelum eksperimen) kemampuan mengapresiasi puisi dan dramadan skor postes (setelah ekperimen) kemampuan mengapresiasi puisi dan dramamenghasilkan $\chi_{\text {hitung }}^{2}=15,16$. Dari tabel distribusi chikuadrat dengan $\mathrm{dk}$ (derajat kebebasan) 1 dan taraf nyata $\alpha=0,05$ diperoleh $\chi_{\text {ttabel }}^{2}=$ 38,4 yang jauh lebih besar daripada $\chi_{\text {hitung }}^{2}$. Dengan demikian, berdasarkan kriteria pengujian, hipotesis nol $\left(H_{0}\right)$ yang menyatakan bahwa skor pretes (sebelum eksperimen) kemampuan mengapresiasi puisi dan dramadan skor postes (setelah 
eksperimen) kemampuan mengapresiasi puisi dan dramaadalah tidak homogen ditolak. Simpulannya ialah bahwa varians skor pretes dan postes kemampuan mengapresiasi puisi dan drama bersifat homogen.

Berdasarkan kedua hasil pengujian persyaratan analisis di atas memberikan simpulan bahwa persyaratan analisis yang diperlukan untuk analisis data dengan teknik statik uji-t non-independen telah terpenuhi, sehingga layak untuk dilakukan analisis lebih lanjut dalam melihat perbedaan pengaruh penggunaan model buku teks pembelajaran puisi dan drama yang apresiatif berbasis tematik integratif, dalam meningkatkan kemampuan mengapresiasi puisi dan dramamahasiswa.

\section{Pengujian Hipotesis}

Pengujian hipotesis di sini maksudkan untuk mengetahui apakah hipotesis nol $\left(\mathrm{H}_{\circ}\right)$ yang diajukan ditolak, atau sebaliknya pada taraf kepercayaan tertentu hipotesis alternatif $\left(\mathrm{H}_{1}\right)$ yang diajukan diterima. Sesuai dengan yang telah disebutkan pada bagian sebelumnya, pengujian hipotesis penelitian diuji dengan teknik statistik uji - t non-independen. Teknik analisis statistik tersebut digunakan untuk melihat perbedaan pengaruh (efektivitas) perlakuan dalam penggunaan model buku teks pembelajaran puisi dan drama yang apresiatif berbasis tematik integratif, dengan yang tidak menggunakan buku teks model tersebut (pada ketika sebelum eksperimen dilakukan).

Efektifivas penggunaan model buku teks pembelajaran puisi dan drama yang apresiatif berbasis tematik integratif, dalam meningkatkan kemampuan mengapresiasi puisi dan dramamahasiswa S1 PGSD daerah Surakarta.

Berdasarkan analisis statistik dengan teknik uji t non-independen diperoleh thitung sebesar 23. Sementara itut-tabel dengan $N=90$ pada taraf $\alpha=0,05$ diketahui sebesar 1,67. Mengacu pada kriteria pengujian hipotesis yang telah dirumuskan bahwa "Ho jika t-hitung > t-tabel pada taraf nyata 0,05 dengan $\mathrm{N}=90$ ". Simpulannya adalah: penggunaan model buku teks pembelajaran puisi dan drama yang apresiatif berbasis tematik integratif sangat efektif dan signifikan dalam meningkatkan kemampuan mengapresiasi puisi dan dramamahasiswa S1 PGSD daerah Surakarta, daripada yang diajar dengan tidak menggunakan model buku teks tersebut.

\section{SIMPULAN}

Tahap eksplorasi menunjukkan bahwa buku teks pembelajaran sastra yang apresiatif yang digunakan di UNS Surakarta, UMS Surakarta, dan UNISRI Surakarta, belum sesuai dengan kebutuhan mahasiswa dan dosen. Tahap pengembangan model 
menghasilkan buku teks pembelajaran puisi dan drama yang apresiatif berbasis tematik integratif melalui preliminary field testing.Berdasarkan analisis statistik dengan teknik uji t non-independen diperoleh t-hitung sebesar 23, dengan nilai t tabel (dengan $\mathrm{N}=90, \alpha=0,05)$ diperoleh 1,67 . Jadi, t-hitung $(23)>\mathrm{t}$-tabel $(1,67)$, maka hipotesis diterima (Ho ditolak). Dengan demikian dapat disimpulkan bahwa Model Buku Teks Bahasa Pembelajaran Puisi dan Drama yang Apresiatif Berbasis Tematik Integratif yang diujicobakan efektif untuk meningkatkan kemampuan mengapresiasi puisi dan drama mahasiswa, sehingga dapat dijadikan alternatif buku teks yang diajarkan. Tahap diseminasi disosialisasikan buku teks pembelajaran puisi dan drama yang apresiatif berbasis tematik integratif, melalui artikel ke jurnal internasional, dan penerbitan buku teks pembelajaran puisi dan drama yang apresiatif berbasis tematik integratif berISBN.

\section{DAFTAR PUSTAKA}

Borg, Walter R. dan Gall, Meredith Damien. 2003. Educational research: An Introduction. New York: Longman.

Cherney, Isabelle D. 2008. The Effects of Active Learning on Student' Memories for Course Content. Journalof Active Learning in Higher Education, Volume 9, No. 2. pp. 152-171. http//alh.sagepub.com/cgi/content/abstract/9/2/152.

Cohen, Louis et al. 2000. Research Method in Education. Great Briatin: TJ International Ltd, Padstow, Cornwall.

Gani, Erizal. 2003. Efektifitas Pengajaran Menulis. Dalam http://www.ialf.edu.html. Diunduh pada tanggal 24 Mei 2018.

Lorenzen, Michael. 2001. Active Learning and Library Instruction (online) dalam http://www.libraryinstruction.com/link.html.

Meyers, Chet \& Jones, Thomas B. 1993. Promoting Active Learning. Jossey-Bass Publisher: San Fransisco.

Miles, Matthew B. dan Huberman, A. Michael. 1992. Analisis Data Kualitatif. (terj. Tjetjeo Rohendi Rohidi)). Jakarta: universitas Indonesia.

Moody, H.L.B. 1971. The Teaching of Literature. London: Longman.

Mustakim, Abdul Wahab. 2010. Psikologi Pendidikan. Jakarta: Rineka Cipta

Nurhidayati. 2011. "Pembelajaran Menyimak Apresiasif Cerita Pendek dengan Strategi Belajar Kooperatif". Litera. 10. (1): 87-99.

Nurkamto, Joko. 1012. "Struktur Penelitian danPenulisan R \& D Bidang Pendidikan (Versi Borg dan Gall)". Makalah Kuliah Umum Program Pascasarjana IKIP PGRI Madiun : 30 September 2012.

Prince, Michael. 2004. Does Active Learning Work: a Review of the Recearch. Journal Engr. Education, 93 (3): 223-2231. Deparment of Chemical Engineering Bucknell University. 
Richard, JC \& Rodgers T. 2002. Approaches and Methods in Language Teaching. Cambridge: Cambridge University Press.

Silberman, Melvin. 2006. Active Learning; 101 Strategi Pembelajaran Aktif. Terj. Sarjuli, et al. Yogyakarta: YAPPENDIS.

Sugiyono. 2013. Metode Penelitian Kuantitatif dan R \& D. Bandung: Alfabeta.

Sukmadinata, Nana Syaodih. 2010. Metode Penelitian Pendidikan. Bandung: Remaja Rosdakarya.

Supriadi, D. 2007. Kreativitas, Kebudayaan, dan Perkembangan Iptek. Bandung: CV Alfabeta

Sutopo, H. B. 2002. Metodologi Penelitian Kualitatif. Surakarta: Sebelas Maret Univercity Press.

Tomlinson,B. \& Masuhara (Eds). 2004. Developing Language Course Materials. Singapore: RELC Portfolio Series.

Wiersma, William. 1986. Research Methods in Education.: An Introduction. Boston: Allyn and Bacon, Inc. 